\author{
GRZEGORZ MATHEA \\ Wyższa Szkoła Bankowa w Warszawie \\ ORCID: 0000-0002-0399-6048
}

\title{
Aktywna neutralność jako element polityki bezpieczeństwa Republiki Irlandii
}

\section{Active neutrality as part of the security policy of the Republic of Ireland}

\begin{abstract}
Unlike the countries that have decided to pursue a policy of neutrality due to historical conditions, such as Austria, Finland, Sweden and Switzerland, the Irish concept of active neutrality seems to be different and original. Separated from continental Europe by England, and later by the United Kingdom, and having gained independence after World War I, Ireland looked for an optimal model for its own security. Due to geographic conditions, a small population and industrial potential, neutrality was the optimal strategy for Ireland's security. This article outlines the evolution of the concept of Irish neutrality ranging from the dogmatic and doctrinal one, based on nineteenth-century designs, to the active, flexible and pragmatic one, adapting to the requirements of a changing world. It also describes the successive stages of the transformation of the neutrality policy which were closely related to the subsequent stages of the Irish state's independence. The paradoxes of Irish neutrality, such as the discrepancy between the official, governmental interpretation of the concept and its social perception, are also presented. The author also attempts to sort out the definitions of neutrality and define the concept of active neutrality.
\end{abstract}

Keywords: neutrality, Ireland, Northern Ireland, Brexit

Słowa kluczowe: neutralność, Irlandia, Irlandia Północna, brexit

\section{Neutralność i pojęcia pokrewne}

Pojęcie neutralność wywodzi się od łacińskiego słowa neuter, które znaczy: 'żaden z dwóch'1. Może to wywołać błędne przekonanie, że termin ten znano i stosowano w czasach starożytnych. Choć niektóre greckie polis

$1 \quad$ P. Andrzejewski, Neutralność w polityce zagranicznej Finlandii i Szwecji, Państwowe Wydawnictwo Naukowe, Warszawa-Poznań 1988, s. 13. 
$\mathrm{w}$ istocie wybierały postawę neutralną (ignorując konflikty innych polis), to jednak ani w czasach hegemonii rzymskiej, ani w okresie feudalizmu w zasadzie nie istniała możliwość trwałego zachowywania przez państwo neutralności. Założeniem Pax Romana było niszczenie lub podporządkowywanie plemion, a relacje feudalne w okresie średniowiecznym czyniły angażowanie się w wojnę jednym z podstawowych obowiązków wasala. Równolegle od czasów starożytnych po współczesne kształtowała się krytyka neutralności jako postawy zachowawczej, niemoralnej, a nawet grzesznej. Potępiał ją Demostenes, Niccolò Machiavelli przestrzegał przed nią władców ${ }^{2}$, a w okresie zimnej wojny postawę państw neutralnych krytykował John Foster Dulles ${ }^{3}$.

Tymczasem ,pojęcie prawne neutralności, z którego wynikają prawa i obowiązki, wykształciło się dopiero na przełomie XVIII i XIX wieku"4. Początkowo rezerwowano je wyłącznie dla określenia stanu prawnego państwa nieuczestniczącego $\mathrm{w}$ wojnie i stopniowo precyzowano: $\mathrm{w}$ deklaracji paryskiej z 1856 r., w deklaracji londyńskiej z 1909 r. oraz w konwencjach haskich z 1907 r. (szczególnie w konwencji V, dotyczącej praw i obowiązków państw neutralnych w razie konfliktu na lądzie, oraz XII, dotyczącej wojny morskiej). Konwencje podzieliły prawa i obowiązki państwa neutralnego na dwie kategorie: pozytywne (sumujące aktywne działania konieczne dla utrzymania neutralności) oraz negatywne (których państwo neutralne powinno się wystrzegać).

Po zakończeniu drugiej wojny światowej, przyjęciu Karty Narodów Zjednoczonych i powstaniu systemów bezpieczeństwa zbiorowego pojęcie neutralności stopniowo zmieniało swoje znaczenie. Dotychczas wiązano je bezpośrednio z działaniami wojennymi, uważając, że charakteryzuje państwa niebiorące udziału w konflikcie ${ }^{5}$. Zróżnicowana postawa państw neutralnych w czasie drugiej wojny światowej sprawiła jednak, że konieczne stało się doprecyzowanie pojęcia w kontekście prawa międzynarodowego.

Piotr Andrzejewski definiuje neutralność jako, ,postawę państwa polegającą na przyjęciu polityki bezstronności, której treść określana jest przez normy

2 N.G. Jesse, Choosing to go it alone. Irish neutrality in theoretical and comparative perspective, „International Political Science Review” 2006, vol. 27, No. 1, s. 12.

3 M. Kowalicka, Polityka neutralności współcześnie, „International Journal of Management and Economics" 2004, vol. 15, s. 176.

4 D. Popławski, Austriacka polityka neutralności. 1955-1995, Scholar, Warszawa 1995, s. 14.

5 P. Andrzejewski, Neutralność..., s. 14. 
prawa międzynarodowego"6. Szerszą definicję podaje Bolesław Balcerowicz, określający neutralność jako:

Niemieszanie się danego państwa bezpośrednio ani pośrednio do sporów innych państw lub toczącej się wojny, połączone z żądaniem nienaruszalności jego granic i praw; prowadzenie przez państwo polityki niewiązania się z polityczno-wojskowymi ugrupowaniami innych państw?

Antonio Papisca rozróżnia neutralność stałą i czasową, zbrojną i niezbrojną, gwarantowaną przez inne państwo lub grupę państw i funkcjonującą bez gwarancji, indywidualną i zbiorową oraz aktywną i pasywną ${ }^{8}$. Neal G. Jesse określa ją z kolei jako „aktywną politykę zagraniczną, prowadzoną w celu powstrzymania się od udziału w międzynarodowym konflikcie".

Analizując postawę państw neutralnych, można podjąć próbę uporządkowania różnych wymiarów pojęcia neutralność. W wymiarze prawnym da się wyróżnić neutralność w kontekście prawnoustrojowym i prawnomiędzynarodowym. Pierwsza wynika z woli suwerennego ustawodawcy krajowego, druga zaś z przepisów traktatowych (jak w przypadku Szwajcarii). W wymiarze politycznym można wyszczególnić dwa pojęcia: politykę neutralności i stan neutralności. Pierwsze oznaczać będzie ogół działań państwa na rzecz powstrzymania się od udziału w konflikcie zbrojnym, a drugie - ogłoszenie neutralności w obliczu toczącego się już konfliktu zbrojnego.

W wymiarze chronologicznym możemy rozróżnić neutralność permanentną i czasową. Neutralność permanentna (zwana też wieczystą lub stałą) oznaczała uzyskanie w umowie międzynarodowej gwarancji niepodległości i integralności terytorialnej.

Państwo wieczyście neutralne zobowiązuje się nigdy nie używać siły zbrojnej przeciwko innemu państwu oraz nie podejmować jakichkolwiek zobowiązań międzynarodowych, które mogłyby wciągnąć je do konfliktu zbrojnego. Konsekwencją tego statusu jest nieprzystępowanie do sojuszy i organizacji wojskowych, zakaz udostępniania swego terytorium obcym bazom wojskowym oraz obowiązek obrony swej neutralności ${ }^{10}$.

6 Tamże, s. 13.

7 B. Balcerowicz, Obronność państwa średniego, Bellona, Warszawa 1997, s. 36.

8 A. Papisca, Active neutrality with the new international law. Reflections from a politics of law perspective, „Peace Human Rights Governance” 2017, vol. 1, No. 3, s. 396.

9 N.G. Jesse, Contemporary Irish neutrality. Still a singular stance, „New Hibernia Review" 2007, vol. 11, No. 1, s. 74.

10 D. Popławski, Austriacka polityka..., s. 16. 
Neutralność czasowa dotyczyła natomiast jedynie konkretnego konfliktu zbrojnego. Balcerowicz utożsamia ją z neutralnością wojenną, twierdząc, że ma zastosowanie

[...] jedynie w przypadku konfliktu zbrojnego; odnosi się zawsze do konkretnego konfliktu i konkretnych państw. Neutralność wojenna nie rozciąga się na czas pokoju, lecz jedynie na czas trwania określonego konfliktu zbrojnego. Warunkiem tej formy neutralności jest powstrzymywanie się od udziału w konflikcie zbrojnym (niebranie udziału w wojnie) ${ }^{11}$.

Można jeszcze rozważyć neutralność w aspekcie motywacyjnym, rozróżniając państwa, które decydują się przyjąć taką postawę w nadziei na uniknięcie skutków wojny, oraz te, które spodziewają się korzyści z wielopłaszczyznowego pośrednictwa między wojującymi stronami.

Obok pojęcia neutralność w literaturze funkcjonują terminy pokrewne: neutralizacja, neutralizm, niezaangażowanie i bezaliansowość.

Bardzo często neutralność stosuje się zamiennie z neutralizacja, która według Andrzejewskiego oznacza ,wynikający z umowy międzynarodowej zakaz działań wojennych na określonym obszarze lub wykorzystywania tego obszaru jako bazy dla prowadzenia operacji wojennych"12. Opinię tę podziela Dariusz Popławski, twierdząc, że neutralizacja może dotyczyć jedynie fragmentu terytorium państwa ${ }^{13}$. W takim rozumieniu może ona zostać narzucona jednemu państwu przez inne, a tym samym naruszać jego suwerenność.

Definicyjnego chaosu nie zmniejszyło pojawienie się po drugiej wojnie światowej pojęcia neutralizm. Użyte w początkach IV Republiki Francuskiej na określenie pryncypiów jej polityki zagranicznej, miało ono oznaczać nieprzystępowanie do bloków militarnych i pokojową współpracę ze wszystkimi państwami niezależnie od ich ustroju ${ }^{14}$. Potwierdza to Andrzejewski, pisząc, że neutralizm

[...] znajduje swe oparcie nie w traktacie międzynarodowym, wyraźnie precyzującym określone prawa i obowiązki danego państwa, lecz w jednostronnej woli zainteresowanego państwa. Oznacza politykę wstrzymywania się od uczestnictwa w sojuszach wojskowych w czasie pokoju. Jego istota sprowadza się do nieprzystępowania do bloków militarnych

11 B. Balcerowicz, Obronność..., s. 36.

12 P. Andrzejewski, Neutralnośćc..., s. 23-24.

13 D. Popławski, Austriacka polityka..., s. 17.

14 M. Kowalicka, Polityka..., s. 175. 
i rozwijania współpracy ze wszystkimi krajami, niezależnie od ustroju politycznego, na zasadach pokojowego współistnienia ${ }^{15}$.

W tym kontekście Popławski przytacza też pojęcie bezaliansowość, odnoszące się do państw, „które w swej polityce bezpieczeństwa wybierają opcję pozostawania poza sojuszami wojskowymi" ${ }^{16}$.

Po drugiej wojnie światowej, wraz z uformowaniem się dwóch bloków polityczno-wojskowych, popularność zyskało również zjawisko nazywane terminem niezaangażowanie, przez część badaczy uznawane za formę neutralności. Wspólnym elementem neutralności i niezaangażowania jest polityka nieprzystępowania do bloków i sojuszy wojskowych. Niezaangażowanie nie wyłącza jednak państwa jako strony wojującej, co potwierdzają liczne przykłady konfliktów z epoki dekolonizacji. Popławski podkreśla różnicę między tymi pojęciami: ,[...] neutralność jest statusem prawnomiędzynarodowym, odwołującym się do prawa neutralności, natomiast niezaangażowanie jest zasadą polityki zagranicznej"17.

Zróżnicowanie modelu neutralności w powołujących się na nią państwach pozwala zrozumieć mnogość definicji i problemy z ich ujednoliceniem. Niniejsza praca pokazuje, że nawet w jednym państwie - w zależności od jego sytuacji wewnętrznej i międzynarodowej - można wyróżnić kilka podejść do neutralności. Wśród kryteriów różnicujących charakter neutralności państwa należy wskazać dobór instrumentów, którymi posługuje się ono w polityce zagranicznej i obronnej, oraz okoliczności, w jakich zdecydowało się na neutralność.

Najbardziej znana i najlepiej przeanalizowana jest neutralność Szwajcarii. To nie tylko charakterystyczna cecha polityki zagranicznej tego państwa, ale już niemal element tożsamości narodowej Szwajcarów. Choć de facto narzucono ją Szwajcarii po kongresie wiedeńskim w 1815 r., to z uwagi na wielowiekową tradycję zaimplementowana została tam bez oporów. W połączeniu z uwarunkowaniami geograficznymi polityka neutralności pozwoliła Szwajcarom uniknąć udziału w konfliktach toczonych w Europie w połowie XIX w. oraz w obu wojnach światowych. Przyjęty przez nich model bez wątpienia można nazwać neutralnością zbrojną ${ }^{18}$, m.in. z uwagi na unikatowe funkcjonowanie sił

15 P. Andrzejewski, Neutralność..., s. 25.

16 D. Popławski, Polityka neutralności i bezaliansowości, [w:] Poziomy analizy stosunków międzynarodowych, red. E. Haliżak, M. Pietraś, Rambler, Warszawa 2013, s. 105.

17 Tamże.

18 N.G. Jesse, Choosing..., s. 15. 
zbrojnych kraju. Na podobnych filarach opiera się model szwedzki, bo i w tym przypadku początkiem neutralności było zakończenie wojen napoleońskich, a położenie geograficzne ułatwiło unikanie zaangażowania w konflikty zbrojne. Problemem był jednak brak izolacjonistycznych tradycji Szwecji i agresywna postawa wobec otoczenia, szczególnie w XVI i XVII w., co wymagało przeorientowania całej polityki zagranicznej państwa. Podczas drugiej wojny światowej państwo szwedzkie zachowało neutralność, ale gospodarczo wspierało wysiłki III Rzeszy i zezwalało na transfer niemieckich wojsk przez swoje terytorium. Przykłady Szwecji i Szwajcarii ukazują istotną różnicę między państwem neutralnym a niebiorącym udziału w wojnie.

Austria i Finlandia, w odróżnieniu od Szwajcarii i Szwecji, dołączyły do grona państw neutralnych dopiero po drugiej wojnie światowej. Polityka neutralności została im narzucona przez ZSRR przy akceptacji pozostałych uczestników układów jałtańskich i poczdamskich. Model fiński - z uwagi na sąsiedztwo ZSRR - stanowił przypadek szczególny ${ }^{19}$. Zachowanie neutralności i akceptacja ograniczeń w polityce zagranicznej za cenę nieingerencji w politykę wewnętrzną przyczyniła się nawet do powstania terminu finlandyzacja. W przypadku Austrii deklaracja neutralności była ceną za wycofanie z jej terytorium wojsk radzieckich i odzyskanie suwerenności.

\section{Geneza neutralności Irlandii}

Koncepcja neutralności Irlandii pojawiła się w tamtejszej myśli politycznej na przełomie XVIII i XIX w. Promowali ją irlandzcy bohaterowie narodowi rewolucjonista Theobald Wolfe Tone i wybitny polityk Daniel O'Connell ${ }^{20}$. $\mathrm{Z}$ drugiej strony większość irlandzkich patriotów wiązała nadzieje na sukces antybrytyjskiego powstania z interwencją któregoś z wrogich Wielkiej Brytanii mocarstw, co trudno wiązać z postawą neutralną.

$\mathrm{Z}$ racji położenia geograficznego Irlandia znajdowała się na peryferiach Europy zarówno w sensie geograficznym, jak i politycznym. Przytoczone wyżej przykłady pokazały, że są to warunki sprzyjające neutralności, ale hegemoniczny charakter relacji z najbliższym sąsiadem - Anglią (a następnie Wielką Brytanią) powodował, że praktyczna realizacja idei neutralności możliwa była dopiero po zakończeniu trwającej w latach 1919-1921 partyzanckiej wojny irlandzko-brytyjskiej. Irlandia podpisała wówczas z Wielką Brytanią traktat,

19 Zob. D. Popławski, Austriacka polityka..., s. 28-29.

20 K. Devine, Review of Ireland's foreign policy and external relations, Dublin 2013, s. 4. 
w którym uzyskała status autonomiczny. Sankcjonował on też podział wyspy: 26 hrabstw południowych uzyskało status dominium jako Wolne Państwo Irlandzkie (WPI), a 6 północnych (gdzie większość mieszkańców stanowili lojalni wobec korony protestanci) - autonomię w ramach Zjednoczonego Królestwa jako Irlandia Północna.

WPI od początku próbowało zaznaczyć swoją samodzielną obecność na arenie międzynarodowej. Bolesne wydarzenia z lat 1916-1923, gdy Irlandia doświadczyła kolejno powstania, wojny partyzanckiej, podziału wyspy i wojny domowej, skłaniały polityków do poszukiwania rozwiązań gwarantujących państwu maksymalny stopień niezależności.

W pierwszym okresie autonomii Irlandia lawirowała w polityce międzynarodowej. Z jednej strony w 1935 r. poparła sankcje ekonomiczne nałożone na Włochy po inwazji Benita Mussoliniego na Etiopię ${ }^{21}$, z drugiej zaśs starała się utrzymywać politykę niezaangażowania w stosunku do obu stron walczących w hiszpańskiej wojnie domowej. Z uwagi na skromny potencjał ludnościowy i militarny Zielonej Wyspy neutralność wydawała się dla niej rozwiązaniem optymalnym. Dla części polityków WPI była ona również sposobem na uniezależnienie się od Wielkiej Brytanii i uniknięcie wmieszania w konflikty z jej udziałem. Rząd Éamona de Valery ${ }^{22}$ widział w neutralności trzy zasadnicze korzyści: uniknięcie wciągnięcia kraju w konflikt zbrojny, uniknięcie wojny z Irlandią Północną, próbę generalną przed osiągnięciem formalnej niepodległości. Dodatkową motywacją był brak większej możliwości manewru, ponieważ zawiązanie sojuszu z jakimkolwiek liczącym się państwem europejskim potraktowane byłoby przez Wielką Brytanię jako zagrożenie, a alians z Londynem z oczywistych względów nie wchodził w grę. Neutralność pozostała więc jedyną opcją, tym bardziej korzystną, że cieszyła się poparciem znaczącej większości Irlandczyków.

W 1937 r. w Irlandii uchwalono konstytucję, która faktycznie znosiła status dominialny i jej nominalną podległość koronie za pośrednictwem Wspólnoty Brytyjskiej. Przyjęcie dokumentu zbiegło się w czasie z forsowaną przez rząd Neville'a Chamberlaina polityką appeasementu ${ }^{23}$. Umożliwiła ona rewizję

21 N.G. Jesse, Choosing to..., s. 10.

22 Éamon de Valera (1882-1975), irlandzki polityk, uczestnik powstania wielkanocnego. Lider partii Sinn Féin, a od 1926 r. - założonej przez siebie Fianna Fáil. Premier Wolnego Państwa Irlandzkiego (1932-1937), Éire (1937-1948) i Republiki Irlandii (1951-1954, 1957-1959), a później prezydent Republiki Irlandii (1959-1973).

23 Polityka appeasementu - ugodowa postawa rządu brytyjskiego wobec roszczeń III Rzeszy w drugiej połowie lat trzydziestych XX w. Choć kojarzona głównie z relacjami brytyjsko-niemieckimi, obejmowała szersze spektrum ustępstw Wielkiej Brytanii, m.in. w kwestiach kolonii, terytoriów zależnych i członków Wspólnoty Brytyjskiej, w tym Irlandii. 
postanowień anglo-irlandzkiego traktatu z 1921 r. w kwestiach bezpieczeństwa, w wyniku czego w 1938 r. pod irlandzką jurysdykcję wróciły wszystkie porty i bazy wojskowe na terenie 26 południowych hrabstw.

Testem trwałości granic polityki neutralności stała się druga wojna światowa. Choć przez cały czas trwania konfliktu alianci naciskali na Irlandię, by się jej wyrzekła, to nie uzyskali jednoznacznych rezultatów. Przynależność Irlandii do Wspólnoty Brytyjskiej ${ }^{24}$ powodowała, że Londyn oficjalnie nigdy nie uznał jej neutralności. Nie udzielił też Irlandii gwarancji, co podważało jej status w myśl interpretacji, że neutralność musi zostać uznana przez obie wojujące strony ${ }^{25}$. Politykę neutralności Irlandii komplikował dodatkowo podział wyspy. W będącej częścią Zjednoczonego Królestwa Irlandii Północnej stacjonowały wojska brytyjskie, a w późniejszej fazie wojny także amerykańskie. Kwestia ta miała się nawet stać przedmiotem targu: część historyków twierdzi, że premier Winston Churchill rozważał zaproponowanie irlandzkiemu rządowi zgody na zjednoczenie $\mathrm{w}$ zamian za przystąpienie do wojny po stronie aliantów. Jako dowód przytaczany jest telegram wysłany do de Valery w grudniu 1941 r. (tuż po przystąpieniu do wojny USA), w którym zostało to sformułowane w dość enigmatyczny sposób ${ }^{26}$.

Polityka neutralności nie mogła wszakże nie uwzględniać strategicznej pozycji Irlandii dla Zjednoczonego Królestwa. W przeszłości mocarstwa europejskie niemal zawsze brały tę wyspę pod uwagę, planując inwazję na Wielką Brytanię ${ }^{27}$. Mimo żywych antybrytyjskich resentymentów Irlandia - podobnie jak Szwecja, a w wielu aspektach również Szwajcaria - poczyniła na rzecz Londynu szereg koncesji, wśród których znalazły się: cicha zgoda na wstępowanie Irlandczyków do brytyjskiej i amerykańskiej armii, ułatwienie dotarcia do Irlandii Północnej zestrzelonym nad Irlandią alianckim lotnikom, otwarcie części przestrzeni powietrznej dla alianckiego lotnictwa oraz współpraca wywiadowcza, dzięki której irlandzki sztab generalny poznał szczegóły niemieckiego

24 Po roku 1937 Irlandia dystansowała się od członkostwa we Wspólnocie Brytyjskiej i nie wysyłała swoich przedstawicieli na jej spotkania. Zob. Historia Irlandii, red. T.W. Moody, F.X. Martin, Zysk i S-ka, Poznań 1998, s. 327; W. Konarski, Pragmatycy $i$ idealiści. Rodowód, typologia $i$ ewolucja ugrupowań politycznych nacjonalizmu irlandzkiego $w X X$ wieku, Uniwersytet Warszawski, Wyższa Szkoła Humanistyczna, Warszawa-Pułtusk 2001, s. 183.

25 Zob. K. Devine, A comparative critique of the practice of Irish neutrality in the ,unneutral” discourse, „Irish Studies in International Affairs” 2008, vol. 19, s. 10.

26 Tamże, s. 15. Zob. też: P. Toboła-Pertkiewicz, De Valera. Gigant polityki irlandzkiej i jego epoka, Prohibita, Warszawa 2015, s. 146.

27 Zob. G. Mathea, Bezpieczeństwo Wysp Brytyjskich w kontekście procesu pokojowego w Irlandii Pótnocnej, Towarzystwo Naukowe Powszechne, Warszawa 2017, s. 126-127. 
planu inwazji na wyspę - tzw. Planu Zielonego (Fall Grün $)^{28}$. Z drugiej strony w warstwie retorycznej i symbolicznej rząd de Valery ortodoksyjnie przestrzegał zasad neutralności, czego wyrazem było utrzymywanie przez całą wojnę stosunków dyplomatycznych z III Rzeszą. W literaturze często przytacza się również fakt złożenia przez de Valerę kondolencji po śmierci Adolfa Hitlera i wpis do księgi kondolencyjnej wyłożonej w niemieckiej ambasadzie w Dublinie ${ }^{29}$.

Bilans polityki neutralności prowadzonej przez Irlandię w trakcie drugiej wojny światowej jest niejednoznaczny. Oparła się naciskom USA i Wielkiej Brytanii, pozostając jednym z 5 na 22 państwa, któremu udało się utrzymać formalną neutralność przez cały okres wojny, ale za cenę faktycznej współpracy z Wielką Brytanią i USA na rzecz ich wysiłku wojennego ${ }^{30}$. Niewątpliwym sukcesem przyjętej polityki było uniknięcie strat ludzkich i materialnych oraz potwierdzenie w oczach całego świata suwerenności Irlandii. Przyczyniło się to również do dalszego wzrostu poparcia idei neutralności przez Irlandczyków. Spośród skutków negatywnych najbardziej dotkliwe było wpędzenie kraju w kilkuletnią izolację na arenie międzynarodowej. Jako państwo neutralne Irlandia nie była uczestnikiem konferencji w San Francisco w kwietniu 1945 r., a na przełomie lat czterdziestych i pięćdziesiątych jej starania o przystąpienie do ONZ torpedował ZSRR - w odwecie za sprzeciw Dublina wobec jego akcesji do Ligi Narodów przez wybuchem drugiej wojny światowej. Mimo amerykańskich nacisków Irlandia odmówiła też przystąpienia do $\mathrm{NATO}^{31}$.

\section{Transformacja polityki neutralności Irlandii}

W 1948 r. rząd w Dublinie ostatecznie zerwał więzy z koroną brytyjską, proklamując Republikę Irlandii. Zakończył się tym samym dziesięcioletni okres funkcjonowania Irlandii w nie do końca określonym statusie międzynarodowym. Nowa republika wystąpiła ze Wspólnoty Brytyjskiej² ${ }^{32}$ a w 1955 r.,

28 Tamże, s. 99.

29 Często, również w polskiej literaturze, przytacza się to jako przykład skrajnie dogmatycznej neutralności Irlandii. Por. S. Grzybowski, Historia Irlandii, Zakład Narodowy im. Ossolińskich, Wrocław 1998, s. 288; P. Toboła-Pertkiewicz, De Valera ..., s. 149. Autentyczność tego wydarzenia podważa jednak Karen Devine. Zob. K. Devine, A comparative critique..., s. 15-18.

30 N.G. Jesse, Choosing..., s. 13.

31 Ireland and the Second World War. Politics, society and remembrance, ed. B. Girvin, G. Roberts, Four Courts Press, Dublin 2000, s. 17.

32 J.W. Averette, At the periphery of incident. Irish neutrality and EU defense policy, National Defense Intelligence College, Washington 2009, s. 22. 
mimo sprzeciwu zwolenników ortodoksyjnej neutralności, przystąpiła wraz z Austrią do ONZ. Irlandia znalazła też sposób na zaznaczenie swojej pozycji na arenie międzynarodowej: wykorzystując okazję, którą był proces dekolonizacji, jako była kolonia brytyjska wyzwolona spod zwierzchnictwa metropolii postanowiła wspierać narody wybijające się na niepodległość. Od początku obecności państwa w strukturach ONZ do chwili obecnej (2018 r.) irlandzcy żołnierze wzięli udział w 54 misjach pokojowych, m.in. w Ameryce Środkowej, Gruzji, byłej Jugosławii, Kambodży, Iranie, Iraku, Afganistanie, Kuwejcie, Kongu, Libanie, Angoli, Namibii, Saharze Zachodniej, Cyprze, Wybrzeżu Kości Słoniowej, Liberii, Timorze Wschodnim i Czadzie. Łączna liczba irlandzkich żołnierzy, których zaangażowano w misje ONZ, wynosi ponad 56 tys. ${ }^{33}$

Udział Republiki Irlandii w misjach pokojowych pozwolił na pierwszą znaczącą redefinicję irlandzkiej neutralności, czego wyrazem było rosnące zainteresowanie rządu w Dublinie procesem ekonomicznej integracji Europy. Wywołało to dyskusję na temat charakteru irlandzkiej neutralności oraz zagrożeń, jakie niesie dla niej ingerencja europejska. Argumenty ekonomiczne i silne powiązanie irlandzkiej gospodarki z Wielką Brytanią przechyliły szalę na stronę zwolenników wejścia Irlandii do Europejskiej Wspólnoty Gospodarczej. Ścisłe rozgraniczenie kwestii gospodarczych (EWG) od militarnych (NATO) pozwoliło uspokoić sceptyków zaniepokojonych możliwością naruszenia neutralności. W 1973 r. Irlandia ostatecznie dołączyła do Wspólnoty wraz z Wielką Brytanią i Danią. Mimo to sprawy zagraniczne stanowiły margines irlandzkiej debaty publicznej. Jak podkreśla Karen Devine, obie główne partie polityczne - Fianna Fáil i Fine Gael - skupiały się na sprawach wewnętrznych, a formułowanie polityki zagranicznej pozostawiły wąskiej grupie ekspertów ${ }^{34}$. Było to przyczyną rosnącego rozdźwięku między oficjalną, rządową interpretacją pojęcia neutralności a rozumieniem go przez opinię publiczną. Na przełomie lat siedemdziesiątych i osiemdziesiątych czołowi irlandzcy politycy wręcz unikali słowa neutralność, zastępując je mniej konkretnymi formułami, jak ,pozostawanie poza sojuszami militarnymi”, ,promocja niezależnych działan”, ,,promowanie naszej wizji spraw

33 P. Schwanberg, Ireland's neutrality and European Security Policy Integration, University of Twente, Münster 2012, s. 20.

$34 \mathrm{~K}$. Devine, Irish political parties attitudes towards neutrality and the evolution of the EU's foreign, security and defence policies, „Irish Political Studies” 2009, vol. 24, No. 4, s. 474. 
zagranicznych”, „rozwiązywanie konfliktów międzynarodowych w drodze pokojowych, politycznych i dyplomatycznych środków"35.

Wyraźną zmianę w retoryce Dublina odnośnie do neutralności wymusił dopiero brytyjsko-argentyński konflikt o Falklandy. Początkowo Irlandia poparła sankcje EWG nałożone w 1982 r. na Argentynę, ale wycofała się z nich, gdy w maju tego roku argentyński krążownik General Belgrano został zatopiony przez brytyjski okręt podwodny, w wyniku czego zginęło 321 marynarzy. Poparcie sankcji w obliczu zatopienia okrętu było dla Dublina nie do pogodzenia z polityką neutralności wobec stron tego konfliktu ${ }^{36}$. Dalsze zaostrzenie debaty na temat neutralności państwa nastąpiło $\mathrm{w}$ drugiej połowie lat osiemdziesiątych, wraz z pojawieniem się koncepcji wspólnego rynku europejskiego. Ratyfikacja Jednolitego aktu europejskiego, który miał go ustanowić, napotkała opór Irlandii, co stało się początkiem tradycji odrzucania przez nią kolejnych traktatów wspólnotowych i unijnych (zob. tabelę). Przyczyną takiej decyzji była obawa irlandzkiej opinii publicznej o zachowanie polityki neutralności.

W latach osiemdziesiątych ukształtował się kolejny model irlandzkiej neutralności, która ewoluowała od restrykcyjnego izolacjonizmu w stronę bardziej otwartej formuły, uwzględniającej wymogi integracji europejskiej i globalizacji. Nowy model zakładał: wsparcie dla udziału w misjach pokojowych ONZ, inicjatyw nierozprzestrzeniania broni jądrowej i procesów dekolonizacyjnych, sprzeciw wobec polityki apartheidu w RPA i finansowania przez USA formacji paramilitarnych w Ameryce Południowej, poparcie dla przyjmowania uchodźców, pomoc państwom trzeciego świata i wreszcie wsparcie dla samostanowienia Palestyńczyków ${ }^{37}$.

Irlandia dołączyła do Wspólnoty Europejskiej jako pierwsze spośród państw stosujących politykę neutralności. Pozostałe: Austria, Szwecja i Finlandia wstąpiły do Unii Europejskiej w 1995 r. en bloc, 22 lata po Irlandii. Generalnie potwierdza to tezę Popławskiego, że w Europie „do końca lat 80. doktryna i praktyka neutralności opierały się na założeniu niedopuszczalności uczestnictwa w uniach celnych i gospodarczych. Wykluczano albo zasadniczo ograniczono możliwość udziału w ponadnarodowych strukturach współpracy integracyjnej”38.

35 Tamże, s. 476.

36 R. Finnegan, Irish Neutrality?, ,Signal Magazine”, Winter 2002, s. 27.

37 K. Devine, Review..., s. 5.

38 D. Popławski, Polityka..., s. 109. 
Kolejnym wyzwaniem dla irlandzkiej polityki neutralności była zmiana sytuacji geopolitycznej po 1989 r. Upadek systemu dwubiegunowego i rozwiązanie Układu Warszawskiego zmusiły NATO do poszukiwania nowej formuły działania. Nałożył się na to dostrzegalny na początku lat dziewięćdziesiątych trend przekazywania przez ONZ mandatu do wykonywania działań pokojowych regionalnym organizacjom bezpieczeństwa. Przykładem były misje SFOR i KFOR w byłej Jugosławii - wyposażone w mandat ONZ, ale prowadzone pod parasolem NATO. Irlandzka neutralność okazała się więc niekompatybilna z nowymi formami kooperacji międzynarodowej na rzecz bezpieczeństwa. Reakcją rządu w Dublinie były kolejne modyfikacje ustawy o obronności z 1960 r. ${ }^{39}$ : w 1993 r. dopuszczono możliwość wzięcia udziału w operacjach wymuszania pokoju, a w 2006 - w operacjach UE, NATO i Unii Afrykańskiej oraz uczestnictwo irlandzkich żołnierzy w ćwiczeniach wojskowych poza granicami kraju ${ }^{40}$. Oznacza to zmianę formuły udziału armii irlandzkiej w misjach zagranicznych i dostosowanie jej do zmieniających się warunków geopolitycznych.

1 grudnia 1999 r. Irlandia przystąpiła do programu Partnerstwo dla Pokoju $(\mathrm{PdP})^{41}$, choć wbrew obietnicom rządzącej partii Fianna Fáil nie poddano tej kwestii pod głosowanie w referendum. Trzy lata wcześniej do PdP włączyła się neutralna Szwajcaria, co z pewnością miało wpływ na decyzję rządu w Dublinie. Nie bez znaczenia było też zapewne podpisanie w 1998 r. porozumienia wielkopiątkowego, które kończyło konflikt w Irlandii Północnej. Wątpliwości budziła co prawda możliwość przejęcia dowództwa nad irlandzkimi oddziałami przez Brytyjczyków, ale nie zaważyło to na ostatecznej decyzji.

W ramach Wspólnej Polityki Bezpieczeństwa i Obrony (WPBiO) Irlandia włączyła się w tworzenie Grup Bojowych Unii Europejskiej i ich działania. Koncepcja powstania tych oddziałów zrodziła się w 2004 r. w trakcie irlandzkiej prezydencji w UE. Rząd w Dublinie zdecydował też o akcesji do Nordyckiej Grupy Bojowej - zarówno ze względu na położenie geograficzne, jak i obecność w niej państw neutralnych - Szwecji i Finlandii ${ }^{42}$.

39 Defence (Amendment) (No. 2) Act, 1960, dostępny w internecie [dostęp: 17 X 2018]: $<$ http://www.irishstatutebook.ie/eli/1960/act/44/enacted/en/html $>$.

40 D. Sweeney, Ireland, the Lisbon referendums, and the ongoing debate on European security, „Global Studies Journal” 2016, vol. 9, issue 1, s. 46.

41 Relations with Ireland, „North Atlantic Treaty Organization” [online], 12 X 2018 [dostęp: 17 X 2018], dostępny w internecie: <http://www.nato.int/cps/en/natohq/topics_51979.htm>.

42 Green Paper of Defence, Department of Defence, Newbridge 2013, s. 20. 
Transformacja irlandzkiej neutralności w latach dziewięćdziesiątych otwiera kolejny, trzeci już etap - aktywną neutralność. Definiująca to pojęcie Devine zalicza do niej promocję pokoju środkami dyplomatycznymi, wyrzeczenie się agresji, uznanie zwierzchniej roli ONZ, uczestniczenie sił zbrojnych w misjach pokojowych ONZ, unikanie zaangażowania w wojny, utrzymanie niepodległości, suwerenności i tożsamości narodowej oraz niezależności własnej polityki zagranicznej, szczególnie w obliczu nacisków ze strony mocarstw ${ }^{43}$. Analizując priorytety irlandzkiej polityki zagranicznej, można uzupełnić tę definicję o realizowanie roli mediatora w konfliktach międzynarodowych oraz udostępnienie terytorium państwa dla siedzib organizacji międzynarodowych.

Ewolucja irlandzkiej neutralności nie naruszyła jej fundamentu, jakim jest unikanie wiązania się sojuszami o charakterze wojskowym. Badania opinii publicznej w 1996 r. pokazały, że za przystąpieniem do NATO opowiada się jedynie 13 proc. obywateli ${ }^{44}$. Poparcie dla zachowania neutralności wzmacniają międzynarodowe konflikty zbrojne. W 1991 i 1992 r. odpowiednio 69 i 71 proc. Irlandczyków sprzeciwiało się udziałowi Irlandii w pierwszej wojnie w Zatoce Perskiej, a w 2003 r. przeciwko zaangażowaniu się w drugą wojnę w tym regionie opowiadało się 81 proc. $\mathrm{z}$ nich ${ }^{45}$.

Obawa o naruszenie neutralności wciąż pozostaje głównym czynnikiem warunkującym poparcie Irlandczyków dla kolejnych etapów integracji europejskiej. Od momentu rozpoczęcia w $1961 \mathrm{r}$. negocjacji akcesyjnych do EWG Dublin wielokrotnie prezentował $\mathrm{w}$ tej sprawie nieustępliwe i bezkompromisowe stanowisko. Każda większa rewizja wspólnotowych traktatów spotykała się z nieufnością i oporem ze strony Irlandii, która każdorazowo zabiegała o zapewnienie sobie gwarancji neutralności. Dopóki EWG skupiała się na kwestiach ekonomicznych, Dublin nie zgłaszał poważniejszych zastrzeżeń. Sytuacja zmieniła się, gdy w połowie lat osiemdziesiątych w Brukseli uwidoczniły się tendencje do stopniowego poszerzania zakresu kompetencji organów Wspólnoty, co znalazło odzwierciedlenie w kolejnych traktatach europejskich. Poniższa tabela przedstawia najważniejsze traktaty reformujące EWG i UE oraz stosunek Irlandii do proponowanych zmian w kontekście neutralności państwa.

43 K. Devine, Review..., s. 6.

44 Tamże, s. 9.

45 Tamże, s. 8. 
Tabela. Traktaty reformujące Europejską Wspólnotę Gospodarczą i Unię Europejską w percepcji Republiki Irlandii (1987-2008)

\begin{tabular}{|c|c|c|}
\hline Traktat & Kwestie sporne & Rezultat \\
\hline \begin{tabular}{|l|}
$1987 \mathrm{r}$. \\
Jednolity akt \\
europejski \\
(JAE)
\end{tabular} & $\begin{array}{l}\text { Irlandzki sąd najwyższy orzekł, że } \\
\text { ratyfikacja aktu jest niezgodna } \\
\text { z konstytucją Irlandii. Wątpliwości } \\
\text { budził tytuł III, zawierający } \\
\text { Postanowienia Traktatu w sprawie } \\
\text { wspótpracy europejskiej w dziedzinie } \\
\text { polityki zagranicznej. } \\
\text { Sprzeciw Irlandii wzbudził } \\
\text { projekt przekazania przez państwa } \\
\text { członkowskie części uprawnień } \\
\text { dotyczących wspólnej polityki } \\
\text { zagranicznej i wzmocnienie roli } \\
\text { Parlamentu Europejskiego. Sąd } \\
\text { najwyższy Irlandii stwierdził, że } \\
\text { zmiany treści traktatu wymagają } \\
\text { przyjęcia poprawki do konstytucji, } \\
\text { co z kolei musiało być zatwierdzone } \\
\text { w ogólnonarodowym referendum }\end{array}$ & $\begin{array}{l}26 \text { V } 1987 \text { r. Irlandczycy zatwierdzili } \\
\text { traktat w referendum stosunkiem głosów } \\
69,9 \text { do } 30 \text { proc. przy frekwencji } 44 \text { proc., } \\
\text { co zaowocowało wejściem JAE w życie } \\
1 \text { VII } 1987 \text { r.* } \\
\text { Postanowienia tytułu III JAE } \\
\text { zinterpretowano jako ogólne kierowanie } \\
\text { się zasadami prawa międzynarodowego } \\
\text { i dążenie do osiągnięcia konsensusu } \\
\text { w polityce zagranicznej**. Ratyfikację } \\
\text { umożliwiło dodanie stosownej (dziesiątej) } \\
\text { poprawki do konstytucji Irlandii. } \\
\text { Jednocześnie zdecydowano, że każda } \\
\text { przyszła zmiana traktatu europejskiego } \\
\text { będzie musiała zostać zatwierdzona } \\
\text { w formie poprawki do konstytucji }\end{array}$ \\
\hline \begin{tabular}{|l|}
$1992 \mathrm{r}$. \\
traktat \\
$\mathrm{z}$ Maastricht
\end{tabular} & \begin{tabular}{|l} 
Traktat przekształcający EWG w Unię \\
Europejską i wprowadzający wspólną \\
walutę nie wzbudził sprzeciwu \\
Irlandii, ponieważ uznano, że nie \\
zmieniał w istotny sposób wspólnej \\
polityki bezpieczeństwa i nie stanowił \\
zagrożenia dla irlandzkiej neutralności. \\
Większość partii politycznych \\
apelowała do głosowania za jego \\
przyjęciem. Wyjątek stanowiły dwa \\
marginalne ugrupowania lewicowe: \\
Lewica Demokratyczna i Partia \\
Zielonych. \\
W dyskusji pojawiła się również kwestia \\
ewentualnej presji UE na zmianę \\
restrykcyjnego irlandzkiego prawa \\
antyaborcyjnego. Rządowi udało się \\
jednak przekonać opinię publiczną, że \\
gwarantowany poprawką konstytucyjną \\
zakaz aborcji nie zostanie zniesiony
\end{tabular} & $\begin{array}{l}18 \text { VI } 1992 \text { r. Irlandczycy zatwierdzili } \\
\text { traktat w referendum stosunkiem głosów } \\
68,7 \text { do } 31 \text { proc. przy frekwencji 57,3 proc. } \\
\text { Ratyfikację umożliwiło dodanie stosownej } \\
\text { (jedenastej) poprawki do konstytucji } \\
\text { Irlandii }\end{array}$ \\
\hline $\begin{array}{l}1997 \mathrm{r} . \\
\text { traktat } \\
\mathrm{z} \text { Amsterdamu }\end{array}$ & $\begin{array}{l}\text { Traktat amsterdamski modyfikował } \\
\text { traktat z Maastricht, m.in. w obszarze } \\
\text { wspólnej polityki zagranicznej } \\
\text { i bezpieczeństwa. Irlandia } \\
\text { z niepokojem obserwowała } \\
\text { zacieśnienie współpracy między } \\
\text { UE i NATO oraz plany powołania } \\
\text { wspólnej, liczącej } 60 \text { tys. żołnierzy } \\
\text { armii europejskiej. } \\
\text { Główne partie polityczne Irlandii } \\
\text { (w tym Lewica Demokratyczna) } \\
\text { optowały za ratyfikacją traktatu. } \\
\text { Przeciwnego zdania były inne } \\
\text { ugrupowania lewicowe: Sinn Fein, } \\
\text { Partia Zielonych oraz marginalna } \\
\text { Partia Socjalistyczna }\end{array}$ & $\begin{array}{l}22 \text { V } 1998 \text { r. Irlandczycy zatwierdzili } \\
\text { traktat w referendum stosunkiem głosów } \\
61,7 \text { do } 38,3 \text { proc. przy frekwencji } \\
56,2 \text { proc. } \\
\text { Ratyfikację umożliwiło dodanie stosownej } \\
\text { (osiemnastej) poprawki do konstytucji } \\
\text { Irlandii. } \\
\text { Referendum w sprawie ratyfikacji traktatu } \\
\text { amsterdamskiego przeprowadzono } \\
\text { jednocześnie z referendum w sprawie } \\
\text { przyjęcia porozumienia wielkopiątkowego. } \\
\text { Fakt ten sprzyjał zwolennikom ratyfikacji, } \\
\text { skupił bowiem uwagę opinii publicznej } \\
\text { na porozumieniu pokojowym kończącym } \\
\text { konflikt w Irlandii Północnej }\end{array}$ \\
\hline
\end{tabular}




\begin{tabular}{|c|c|c|}
\hline Traktat & Kwestie sporne & Rezultat \\
\hline $\begin{array}{l}2001 \mathrm{r} . \\
\text { traktat z Nicei }\end{array}$ & $\begin{array}{l}\text { Poparcie dla traktatu wyraziły } \\
\text { najważniejsze partie polityczne. } \\
\text { Mimo że dokument ten nie wprowadzał } \\
\text { większych zmian w obszarze polityki } \\
\text { bezpieczeństwa (jedyną istotną kwestią } \\
\text { było przeniesienie kompetencji } \\
\text { odnośnie do misji petersberskich } \\
\text { z UZE do UE**), Irlandczycy obawiali } \\
\text { się, że stanowi on zagrożenie dla } \\
\text { pryncypiów polityki zagranicznej } \\
\text { ich państwa, a przede wszystkim dla } \\
\text { neutralności kraju. } \\
\text { Obawy Irlandczyków dotyczyły też } \\
\text { pozycji mniejszych państw w UE } \\
\text { w związku ze zmianą sposobu } \\
\text { podejmowania decyzji }\end{array}$ & $\begin{array}{l}7 \text { VI } 2001 \text { r. Irlandczycy opowiedzieli } \\
\text { się w referendum przeciwko traktatowi } \\
\text { stosunkiem głosów 53,9 do 46,1 proc. przy } \\
\text { frekwencji } 35 \text { proc. } \\
\text { Wynik głosowania był zaskoczeniem } \\
\text { dla elit politycznych Irlandii, państw } \\
\text { UE i krajów negocjujących przyjęcie } \\
\text { do Wspólnoty. Prasa winą za taki rezultat } \\
\text { obarczała rząd, który nie przełożył } \\
\text { w kampanii skomplikowanej i rozwlekłej } \\
\text { treści traktatu na język zrozumiały dla } \\
\text { społeczeństwa. } \\
\text { Rząd wyciągnął wnioski z porażki } \\
\text { i zaplanował drugie referendum, tym razem } \\
\text { podkreślając w kampanii nienaruszalność } \\
\text { irlandzkiej neutralności***. Aby dać } \\
\text { Irlandczykom pewność, 22 VI } 2002 \text { r. } \\
\text { w trakcie spotkania Rady Europejskiej } \\
\text { w Sewilli pozostałe kraje UE przyjęły } \\
\text { gwarantującą to deklarację sewilską. } \\
\text { Drugie referendum w sprawie traktatu } \\
\text { nicejskiego odbyło się } 19 \text { X 2002 r. } \\
\text { Tym razem Irlandczycy zatwierdzili go } \\
\text { stosunkiem głosów 62,9 do } 37,1 \text { proc. przy } \\
\text { frekwencji } 49,5 \text { proc. } \\
\text { Ratyfikację umożliwiło dodanie } \\
\text { stosownej (dwudziestej szóstej) poprawki } \\
\text { do konstytucji Irlandii }\end{array}$ \\
\hline $\begin{array}{l}2008 \mathrm{r} . \\
\text { traktat } \\
\mathrm{z} \text { Lizbony }\end{array}$ & $\begin{array}{l}\text { Po raz kolejny najważniejszą } \\
\text { kwestią debaty przedreferendalnej } \\
\text { była neutralność i po raz kolejny } \\
\text { Irlandczycy wyrażali obawy, że } \\
\text { nowy unijny traktat może być dla } \\
\text { niej zagrożeniem. Sprzeciw budziły } \\
\text { zapisy obligujące sygnatariuszy } \\
\text { do pomocy zaatakowanemu krajowi } \\
\text { członkowskiemu oraz poszerzenie } \\
\text { zakresu misji petersberskich. } \\
\text { Irlandczycy obawiali się też utraty } \\
\text { swojego komisarza w Komisji } \\
\text { Europejskiej i możliwych } \\
\text { niekorzystnych zmian w systemie } \\
\text { podatkowym }\end{array}$ & $\begin{array}{l}12 \text { VI } 2008 \text { r. Irlandczycy odrzucili traktat } \\
\text { lizboński w referendum stosunkiem } \\
\text { głosów 53,4 do 46,6 proc. przy frekwencji } \\
53,1 \text { proc. Oprócz kwestii neutralności } \\
\text { na ich decyzję wpłynął brak dostatecznej } \\
\text { wiedzy na temat założeń traktatu. } \\
\text { Podobnie jak w przypadku traktatu } \\
\text { nicejskiego referendum zostało powtórzone. } \\
2 \text { X } 2009 \text { r. } 67,1 \text { proc. głosujących } \\
\text { powiedziało ,tak”, a przeciw było } \\
32,9 \text { proc. }{ }^{* * * * *} \text { Frekwencja wyniosła } 59 \text { proc. } \\
\text { Rząd uzyskał zmianę nastawienia części } \\
\text { społeczeństwa, zapewniając Irlandii } \\
\text { szereg gwarancji ze strony UE. Dotyczyły } \\
\text { one m.in. nienaruszalności krajowej } \\
\text { legislacji w kwestiach prawa do życia, } \\
\text { rodziny i edukacji. Rada Europejska } \\
\text { zagwarantowała też Irlandii utrzymanie } \\
\text { pełni praw decydowania o polityce } \\
\text { podatkowej i obronnej }\end{array}$ \\
\hline $\begin{array}{rr}* & \text { P. Sch } \\
* * & \text { Por. M } \\
* * * \quad \text { D. Sw } \\
* * * * \quad \text { P. Sch } \\
* * * * * \quad \text { Irelanc } \\
\text { dostępny w int } \\
\text { irlandzkich wy } \\
\text { podaje Seán Ó } \\
\text { Press, Cambrid }\end{array}$ & $\begin{array}{l}\text { vanberg, Ireland's neutrality..., s. } 28 . \\
\text { Kowalicka, Polityka..., s. } 179 . \\
\text { eney, Ireland..., s. } 47 . \\
\text { vanberg, Ireland's neutrality..., s. } 35 \text {. } \\
\text { backs EU's Lisbon Treaty, „BBC New } \\
\text { rnecie: }<\text { http://news.bbc.co.uk/2/hi/828 } \\
\text { gorców i ich nastawienie do instytucji e } \\
\text { Riain: S. Ó Riain, The rise and fall of It } \\
\text { ge } 2014, \text { s. } 259-263 \text {. }\end{array}$ & $\begin{array}{l}\text { nline], } 3 \text { X } 2009 \text { [dostęp: } 20 \text { V 2018], } \\
\text {.stm>. Szczegółowe preferencje } \\
\text { ejskich w kontekście kryzysu finansowego } \\
\text { d's Celtic tiger, Cambridge University }\end{array}$ \\
\hline
\end{tabular}




\section{Perspektywy polityki aktywnej neutralności w Irlandii}

Poparcie Irlandczyków dla neutralności ich państwa od lat utrzymuje się na wysokim poziomie. W latach 1991-1995 zwolennikami prowadzenia takiej polityki było 55-69 proc. obywateli ${ }^{46}$, a w 2001 r., tuż przed referendum w sprawie ratyfikacji traktatu nicejskiego - 72 proc. Szczegółowe badania dowodzą jednak, że pryncypia irlandzkiej neutralności pozostają niejasne dla znaczącej części społeczeństwa. Ankiety przeprowadzone w 1985 i 1992 r. pokazały, że odpowiednio dla 48 i 46 proc. respondentów neutralność oznaczała brak udziału w wojnie lub brak wiązania się sojuszami militarnymi, a 31 i 21 proc. nie potrafiło odpowiedzieć, czym ona jest. Z kolei w 1992 r. aż 75 proc. obywateli poparło udział wojsk irlandzkich w misjach pokojowych pod auspicjami ONZ ${ }^{47}$. Badania opinii przeprowadzone na przełomie 2001 i 2002 r. potwierdzały, że termin neutralność najbardziej kojarzy się Irlandczykom z promocją pokoju, polityką nieagresji, ograniczeniem zagranicznej aktywności armii do działań objętych mandatem ONZ, niezaangażowaniem w wojny oraz utrzymaniem niepodległości, tożsamości i niezależności w polityce zagranicznej ${ }^{48}$.

Devine zwraca uwagę, że badania przeprowadzone w latach 1983-2003 pokazują różnice $\mathrm{w}$ interpretacji irlandzkiej neutralności przez polityków i opinię publiczną. W kołach politycznych dominowało węższe postrzeganie tej idei - zbieżne z przytoczonymi na wstępie definicjami zakładającymi brak udziału w sojuszach wojskowych (military neutrality). Opinia publiczna rozumie ją natomiast szerzej - jako koncept aktywnej neutralności. Z badań wynika, że od dłuższego czasu niezmiennie blisko dwie trzecie Irlandczyków popiera koncepcję neutralności ${ }^{49}$. Równocześnie sondaż przeprowadzony w 2019 r. pokazał, że 58 proc. społeczeństwa popiera aktywny udział państwa w przedsięwzięciach UE w obszarze bezpieczeństwa i obronności ${ }^{50}$.

Irlandzka neutralność wyłamuje się z większości definicji i jest pełna paradoksów: wypełnia na przykład kryteria neutralności stałej, ale nie reguluje

46 N.G. Jesse, Choosing..., s. 20.

47 Tamże.

48 K. Devine, Stretching the IR theoretical spectrum on Irish neutrality. A critical social constructivist framework, „International Political Science Review” 2008, vol. 29, No. 4, s. 13.

49 Taż, Review..., s. 6.

50 Ireland and the EU Poll 2019, „European Movement Ireland” [online, dostęp: 1 X 2019], dostępny w internecie: <https://www.europeanmovement.ie/programmes/ireland-andthe-eu-poll/>. 
tego żaden traktat międzynarodowy ${ }^{51}$. Zdaniem Rory'ego Finnegana irlandzka neutralność zmieniła się w politykę niezaangażowania ${ }^{52}$. Różnicę w warstwie deklaratywnej i faktycznej zauważa też Popławski, twierdząc:

[...] tradycyjne definiowanie neutralności [Irlandii] po konflikcie w Kosowie ustąpiło miejsca bezaliansowości. Jednakże w sferze deklaratoryjnej Dublin pozostaje wciąż w kręgu tradycyjnej interpretacji ,neutralności militarnej”. Wszechobecna retoryka neutralności jest nadal charakterystyczna dla irlandzkiej aktywności, co w decydującym stopniu wynika $\mathrm{z}$ uwarunkowań wewnątrzpolitycznych ${ }^{53}$.

Warto też podkreślić, że do 1998 r. Republika Irlandii poprzez art. 2 i 3 konstytucji z 1937 r. de facto zgłaszała roszczenia terytorialne do całej wyspy, co pozostawało w jawnej sprzeczności z polityką neutralności.

Neutralność Irlandii jest też unikatowa na tle innych neutralnych państw europejskich. W warstwie wojskowej łączy ją z nimi w zasadzie tylko dobrze przemyślany i rozwinięty system mobilizacji rezerw. Nie opiera się ona natomiast na utrzymywaniu znaczącego potencjału militarnego, jak choćby Szwajcaria, która ma zdolność zmobilizowania niemal 10 proc. ludności ${ }^{54}$. Irlandia znajduje się też na końcu listy państw europejskich pod względem wydatków na obronność, które w 2017 r. stanowiły 0,3 proc. jej PKB. Porównywalny wskaźnik ma w Europie tylko Mołdawia, a pozostałe państwa neutralne wydają na obronność więcej: Szwecja - 1 proc., Finlandia 1,4 proc., Austria $-0,7$ proc., Szwajcaria $-0,7$ proc. PKB $^{55}$.

Irlandia oparła się widocznej w Europie tendencji do odchodzenia od neutralności lub korekty na rzecz innych form, np. bezaliansowości, widocznej w polityce Szwecji, Austrii czy Finlandii, szczególnie po akcesji do $U^{56}$. $\mathrm{W}$ większości koncepcji obronnych tych państw neutralność została zaliczona w poczet terminów zimnowojennych lub nawet dziewiętnastowiecznych, a tym samym nieprzystających do współczesnej rzeczywistości, opartej na koncepcjach bezpieczeństwa zbiorowego. Na początku XXI w. zasadnicze

51 Zob. P. Andrzejewski, Neutralnośćc.., s. 22.

52 R. Finnegan, Irish Neutrality?..., s. 31.

53 D. Popławski, Polityka..., s. 119.

54 N.G. Jesse, Choosing..., s. 16.

55 Military expenditure by country as percentage of gross domestic product, 2003-2017, SIPRI 2018, dostępny w internecie [dostęp: 20 V 2018]: <https://www.sipri.org/databases/milex>.

56 Por. D. Popławski, Polityka... O naciskach Komisji Europejskiej na rewizję lub zawężenie polityki neutralności w trakcie negocjacji akcesyjnych z Austrią, Finlandią i Szwecją w pierwszej połowie lat dziewięćdziesiątych pisze też Devine: K. Devine, Review..., s. 8. 
zmiany dotknęły nawet szwajcarską koncepcję neutralności, która wydawała się dotąd nienaruszalna ${ }^{57}$.

Przyjęcie wspólnej waluty i ścisłe związki gospodarcze z Wielką Brytanią skłaniają do refleksji, czy w dłuższej perspektywie utrzymywanie przez Irlandię polityki neutralności jest realne. Nie bez znaczenia są tu również takie zjawiska, jak terroryzm międzynarodowy, cyberprzestępczość czy kryzys migracyjny.

Dogmatyczny stosunek irlandzkiego społeczeństwa do neutralności zaczął szkodzić wizerunkowi Irlandii wewnątrz UE, postrzegana jest bowiem jako kraj zachowawczy, hamujący rozwój Wspólnoty. W dotychczasowych traktatach udało się pogodzić interesy UE i Irlandii zdeterminowanej w utrzymaniu gwarancji neutralności. Żadne inne państwo neutralne nie wykazało dotąd podobnej konsekwencji. Wzrost zagrożeń bezpieczeństwa związany z globalizacją skłania jednak ku postawieniu tezy, że irlandzka neutralność będzie musiała ulec znaczącej transformacji. Jak wykazano wyżej, najważniejsze siły polityczne w kraju traktują ją instrumentalnie. Z drugiej strony wyniki referendów traktatowych pokazują przywiązanie Irlandczyków do neutralności, choć jej sens i znaczenie bywają rozumiane różnie. $Z$ pewnością temat ten wciąż będzie obecny w krajowej debacie publicznej, głównie w warstwie symbolicznej i retorycznej, jako symbol suwerenności i tożsamości narodowej. Równolegle postępować będzie jednak proces osadzania państwa w europejskim systemie bezpieczeństwa, co potwierdza choćby przystąpienie w 2017 r. do unijnego mechanizmu Stałej Współpracy Strukturalnej (Permanent Structured Cooperation, PESCO), który zakłada zwiększenie zobowiązań obronnych, pogłębioną współpracę w zakresie WPBiO oraz audyt Europejskiej Agencji Obrony. Uzasadniając tę decyzję, premier Irlandii Leo Varadkar wskazał listę zagrożeń, wobec których zachowanie neutralności nie jest możliwe: cyberprzestępczość, ingerencję hakerów w procesy wyborcze, handel ludźmi czy kryzys migracyjny ${ }^{58}$.

Wagę Irlandii dla bezpieczeństwa regionu Wysp Brytyjskich i całej Europy pokazują również wydarzenia związane z planowanym wystąpieniem Wielkiej Brytanii z UE. W negocjacjach na temat szczegółów brexitu dominuje kwestia granicy dzielącej Zieloną Wyspę. Choć pragnienie potraktowania jej w wyjątkowy sposób wyrażane jest przez obie strony, to szczegóły funkcjonowania

57 Szerzej: D. Popławski, Polityka..., s. 119-120.

58 Ph. Ryan, ,Neutrality is different now” says Varadkar, „Independent” [online], 24 XII 2017 [dostęp: 14 V 2018], dostępny w internecie: <https://www.independent.ie/irish-news/neutrality-is-different-now-says-varadkar-36434630.html>. 
granicy nadal pozostają niejasne. Gdyby doszło do brexitu bez umowy, polityka neutralności Irlandii zostałaby poddana poważnemu testowi, zwłaszcza w kontekście wzniesienia twardej granicy w poprzek wyspy. Przywrócenie jej w formie fizycznej może istotnie zaburzyć trwający już dwadzieścia lat proces pokojowy w Irlandii Północnej. Ewentualna eskalacja konfliktu z pewnością nie byłaby bez znaczenia dla irlandzkiej polityki neutralności.

\section{Bibliografia}

Andrzejewski P., Neutralność w polityce zagranicznej Finlandii i Szwecji, Państwowe Wydawnictwo Naukowe, Warszawa-Poznań 1988.

Averette J.W., At the periphery of incident. Irish neutrality and EU defense policy, National Defense Intelligence College, Washington 2009.

Balcerowicz B., Obronność państwa średniego, Warszawa 1997.

Defence (Amendment) (No. 2) Act, 1960, dostępny w internecie [dostęp: 17 X 2018]: <http:// www.irishstatutebook.ie/eli/1960/act/44/enacted/en/html>.

Devine K., A Comparative critique of the practice of Irish neutrality in the ,unneutral” discourse, „Irish Studies in International Affairs” 2008, vol. 19.

Devine K., Irish political parties attitudes towards neutrality and the evolution of the EU's foreign, security and defence policies, „Irish Political Studies” 2009, vol. 24, No. 4.

Devine K., Review of Ireland's foreign policy and external relations, Dublin 2013.

Devine K., Stretching the IR theoretical spectrum on Irish neutrality. A critical social constructivist framework, „International Political Science Review” 2008, vol. 29, No. 4.

Finnegan R., Irish Neutrality?, „Signal Magazine”, Winter 2002.

Green Paper of Defence, Department of Defence, Newbridge 2013.

Grzybowski S., Historia Irlandii, Zakład Narodowy im. Ossolińskich, Wrocław 1998.

Historia Irlandii, red. T. W. Moody, F.X. Martin, Zysk i S-ka, Poznań 1998.

Ireland and the EU Poll 2019, „European Movement Ireland” [online, dostęp: 1 X 2019], dostępny w internecie: $<$ https://www.europeanmovement.ie/programmes/ireland-and-the-eu-poll/>.

Ireland and the Second World War. Politics, society and remembrance, ed. B. Girvin, G. Roberts, Four Courts Press, Dublin 2000.

Ireland backs EU's Lisbon Treaty, „BBC News” [online], 3 X 2009 [dostęp: 20 V 2018], dostępny w internecie: $<$ http://news.bbc.co.uk/2/hi/8288181.stm>.

Jesse N.G., Choosing to go it alone. Irish neutrality in theoretical and comparative perspective, „International Political Science Review” 2006, vol. 27, No. 1.

Jesse N.G., Contemporary Irish neutrality. Still a singular stance, „New Hibernia Review” 2007, vol. 11, No. 1.

Konarski W., Pragmatycy i idealiści. Rodowód, typologia i ewolucja ugrupowań politycznych nacjonalizmu irlandzkiego w XX wieku, Uniwersytet Warszawski, Wyższa Szkoła Humanistyczna, Warszawa-Pułtusk 2001.

Kowalicka M., Polityka neutralności wspótcześnie, „International Journal of Management and Economics" 2004, vol. 15.

Mathea G., Bezpieczeństwo Wysp Brytyjskich w kontekście procesu pokojowego w Irlandii Pólnocnej, Towarzystwo Naukowe Powszechne, Warszawa 2017. 
Military expenditure by country as percentage of gross domestic product, 2003-2017, SIPRI 2018, dostępny w internecie [dostęp: 20 V 2018]: <https://www.sipri.org/databases/milex>. Ó Riain S., The rise and fall of Ireland's Celtic tiger, Cambridge University Press, Cambridge 2014. Papisca A., Active neutrality with the new international law. Reflections from a politics of law perspective, „Peace Human Rights Governance” 2017, vol. 1, No. 3.

Popławski D., Austriacka polityka neutralności. 1955-1995, Scholar, Warszawa 1995.

Popławski D., Polityka neutralności i bezaliansowości, [w:] Poziomy analizy stosunków międzynarodowych, red. E. Haliżak, M. Pietraś, Rambler, Warszawa 2013.

Relations with Ireland, „North Atlantic Treaty Organization” [online], 12 X 2018 [dostęp: 17 X 2018], dostępny w internecie: <http://www.nato.int/cps/en/natohq/topics_51979.htm>. Ryan Ph., ,, Neutrality is different now” says Varadkar, „Independent” [online], 24 XII 2017 [dostęp: 14 V 2018], dostępny w internecie: <https://www.independent.ie/irish-news/neutrality-is-different-now-says-varadkar-36434630.html>.

Schwanberg P., Ireland's neutrality and European Security Policy Integration, University of Twente, Münster 2012.

Sweeney D., Ireland, the Lisbon referendums, and the ongoing debate on European security, „Global Studies Journal” 2016, vol. 9, issue 1.

Toboła-Pertkiewicz P., De Valera. Gigant polityki irlandzkiej i jego epoka, Prohibita, Warszawa 2015. 